\title{
Development of the mechanical and barrier properties of collagen hydrolysate/carboxymethyl cellulose films by using $\mathrm{SiO}_{2}$ nanoparticles
}

\author{
Kolajen hidrolizat/karboksimetil selüloz filmlerinin mekanik ve bariyer \\ özelliklerinin $\mathrm{SiO}_{2}$ nanoparçacıkları kullanımı ile geliştirilmesi
}

\author{
Buğra OCAK ${ }^{1}$ iD
}

1Department of Leather Engineering, Faculty of Engineering, Ege University, Izmir, Turkey.

bugraocak@gmail.com

Received/Geliș Tarihi: 18.12.2017, Accepted/Kabul Tarihi: 08.06.2018

* Corresponding author/Yazıșilan Yazar

doi: $10.5505 /$ pajes. 2018.80688 Research Article/Araștırma Makalesi

\begin{abstract}
Pollution is a global problem and the increased use non-biodegradable plastic packaging films have caused environmental concerns. Thus, there is a tendency to use natural polymer materials, such as biodegradable films. This paper aims to prepare and characterize nove collagen hydrolysate/carboxymethyl cellulose/nano-SiO ${ }_{2}$ films for packaging/coating applications. The results indicate that the incorporation of nano-SiO ${ }_{2}$ in films from $1 \%$ to $4 \%$ caused significant increase $(p<0.05)$ in thickness and tensile strength but significantly decreased the elongation at break. Nano-SiO ${ }_{2}$ drastically reduced the water vapor permeability and water solubility values of films. Furthermore, the increments in nano-SiO ${ }_{2}$ proportion in films increased the values of transparency and provided a reduction in the light transmission in the ultraviolet and visible range. This study demonstrates that nano-SiO ${ }_{2}$ addition to collagen hydrolysate/carboxymethyl cellulose films gives significantly effects on properties of film produced. The enhancement of film properties shows the potential for using collagen hydrolysate/carboxymethyl cellulose films for coating/packaging purposes.
\end{abstract}

Keywords: Collagen hydrolysate, Carboxymethyl cellulose, $\mathrm{SiO}_{2}$, Water vapor permeability, Water solubility

\section{Introduction}

The tanning process is a key step for the production of leather from animal skin to leather, in which different chemical substances are used to increase the stability of raw hides/skins [1]-[3]. Presently, about $90 \%$ of leathers are tanned with chromium salts [1]-[4]. Each year, large amount of chrometanned leather waste is generated principally from the mechanical treatments carried out after tanning process such as splitting, buffing, trimming and shaving [1],[5]-[7]. $0.8 \times 10^{6}$ $t$ of chrome shavings are generated from global leather industries and these trivalent chromium containing solid leather wastes require special attention because trivalent chromium can be oxidized to hexavalent chromium which have a negative impact on environment and human health [1],[7],[8]. Large quantities of chromium containing leather waste still goes into land disposal and burning [8],[9]. Collecting, treating and disposing of leather solid waste are now being considered less cost effective and reveals some limitations in its practical application [1],[7],[8]. With increasing concerns for the environment, the pressure of landfilling of leather wastes has increased demands from the leather industry to use effective and clean technologies for leather waste disposal [8],[10]. For ecological and economic reasons, the potential usage of
Öz

Küresel bir sorun olan kirlilik ve biyolojik olarak parçalanmayan plastik ambalaj filmlerinin artan kullanımı çevresel kaygılara neden olmuștur. Dolayısıyla, biyolojik olarak bozunabilir filmler gibi doğal polimer materyalleri kullanma eğilimi artmıștır. Bu makale, paketleme/kaplama uygulamaları için yeni kolajen hidrolizat/karboksimetil selüloz/nano-SiO $\mathrm{O}_{2}$ filmlerini hazırlamayı ve karakterize etmeyi amaçlamaktadır. Sonuçlar, filmlere nano-SiO katılımının \%1'den \%4'e arttırılmasıyla, kalınlı ve çekme mukavemetinde belirgin bir artışa $(p<0.05)$ neden olduğunu, ancak kopma uzamasını önemli ölçüde azalttığını göstermektedir. Nano-SiO ${ }_{2}$, filmlerin su buharı geçirgenliği ve suda çözünürlük değerlerini büyük ölçüde düşürmüştür. Ayrıca, filmlerdeki nano-SiO ${ }_{2}$ oranındaki artışlar șeffaflık değerlerini arttırmıș, ultraviyole ve görünür aralıktaki ıșık geçirgenliğinde azalma sağlamıștır. Bu çalıșma, nano-SiO${ }_{2}^{\prime}$ nin kolajen hidrolizat/karboksimetil selüloz filmlerine ilavesinin, üretilen filmin özellikleri üzerinde önemli etkiler verdiğini göstermektedir. Kolajen hidrolizatı/karboksimetil selüloz filmlerinin özelliklerinin geliștirilmesi, filmlerin kaplama/ambalaj amaçlı kullanım potansiyelini arttıracaktır.

Anahtar kelimeler: Kolajen hidrolizat, Karboksimetil selüloz, $\mathrm{SiO}_{2}$, Su buharı geçirgenliği, Su çözünürlüğü

collagen hydrolysate extracted from leather solid wastes has been investigated for blending it with synthetic and natural polymers in film production [7],[11]-[13].

Over the last 20 years, the production and use of petroleumderived plastic films made from synthetic polymers, such as polystyrene, polyamides, polyethylene terephthalate, polyethylene etc., have been dominating packaging/coating applications in worldwide [14],[15]. Plastics films have wide applications in agriculture, medicine, pharmaceutical, cosmetic, packaging and food industry, but these materials have caused increasing environmental concerns, as a result of their nondegradable, non-renewable nature [13]-[16]. With the increasing environmental concerns over non-biodegradable petroleum based plastics and high oil price, has led to efforts to develop biodegradable packaging materials using biopolymers to substitute for synthetic plastics all over the world [13],[17], [18]. Hence, biopolymer-based packaging materials originating from naturally renewable resources such as polysaccharides, proteins, and lipids from animal, marine, agricultural, or microbial sources. These biopolymers exhibit high potential for usage as an alternative to petroleum derived plastic packaging materials as they are abundant, renewable, inexpensive and biodegradable [15],[18]-[20]. However, biopolymers generally present poor mechanical and barrier properties compared with 
the petroleum derived plastic materials are the main reasons for paying attention to blend with other natural, synthetic polymers or nanomaterials [21]. To overcome these limitations, researches focuses on the films produced by blending of polymers and nanoparticles. Blending is a simple and effective method to enhance the properties of films [15],[21].

Among the renewable sources with film forming ability, protein derivatives have some advances such as low price, nontoxicity and biodegradability properties [14],[15]. Collagen hydrolysate $(\mathrm{CH})$ is a protein based natural polymer found in the bones, skins and connective tissue of animals. $\mathrm{CH}$ has good filmforming properties, biocompatibility, low cost, biodegradability, sustainability, non-toxicity, and abundance [14],[15]. However, $\mathrm{CH}$ has a low molecular weight, poor mechanical stability, brittle, abundant hydrophilic groups and low thermal stability [7]. Nevertheless, CH exhibits some drawbacks for packaging/coating applications, such as poor mechanical stability, brittle, abundant hydrophilic groups and low thermal stability, and need to be modified for packaging/coating requirements [7],[14].

Carboxymethyl cellulose (CMC), which is a chemically modified water-soluble cellulose derivative, is an alternative polymer used for blending with proteins to obtain flexible and strong films, due to its ability to form a continuous matrix, excellent viscosity, biocompatibility, and availability [15],[22]. In biopolymer-based films, CMC also improves the mechanical, thermal and barrier properties of films [14].

In the past decades, nano- $\mathrm{SiO}_{2}$ (NS) have received considerable attention and used in many industrial fields including: catalysis, ceramics, plastics and coatings [19],[23]-[25]. NS, amorphous powder with tridimensional structure, have been widely used as reinforcements to enhance the mechanical, thermal, radiation resistance, barrier, optical, physicochemical and electrical properties of polymeric materials compared to the pure polymers [19],[21],[25]. The NS usually possesses remarkable physico-chemical properties in composite materials, which is attributed to the nano size and strong chemical bonds with the polymers [25],[26].

Compared with the research into mechanical properties, there is no report have been conducted on the mechanical and barrier properties of NS modified CH/CMC films. Therefore, the key objective of this present work was to develop the mechanical and barrier characteristics of CH/CMC films by adding different concentrations of NS to form a potentially new biodegradable film as an alternative material for coating/packaging industry.

\section{Materials and methods}

\subsection{Materials}

The chromium contained leather waste was obtained from a commercial tannery in Izmir, Turkey. Alcalase, silicon dioxide $\left(\mathrm{SiO}_{2} ; 10-20 \mathrm{~nm}\right.$ particle size), carboxymethyl cellulose and glycerol (as plasticizing agent) were purchased from SigmaAldrich (USA). Magnesium oxide was kindly provided from Merck (Germany). All the chemicals used in this study were of analytical grade.

\subsubsection{Extraction of $\mathrm{CH}$ from leather wastes}

The $\mathrm{CH}$ were prepared according to the literature procedure [6].

\subsection{Methods}

\subsubsection{Preparation of $\mathrm{CH} / \mathrm{CMC}$ based films}

Knowing amounts of $\mathrm{CH}$ and $\mathrm{CMC}$ were dissolved separately in distilled water for film preparation. First, collagen hydrolysate (3.0 g of $\mathrm{CH} / 50 \mathrm{ml}$ distilled water) was hydrated at room temperature for $30 \mathrm{~min}$, and solubilized later in a thermostatically controlled water bath at room temperature at $50{ }^{\circ} \mathrm{C}$. Then, $3.0 \mathrm{~g}$ of CMC powder added in $50 \mathrm{ml}$ distilled water in the flask while stirring at $50{ }^{\circ} \mathrm{C}$ for $30 \mathrm{~min}$. Both solutions were mixed and blended together with glycerol (30\%). Various amounts of NS $(0,1,2,3,4 \mathrm{~g} / 100 \mathrm{~g} \mathrm{CH} / \mathrm{CMC})$ were added into $\mathrm{CH} / \mathrm{CMC}$ mixture. The obtained mixture was constantly stirred at $50 \pm 5^{\circ} \mathrm{C}$ for $30 \pm 5 \mathrm{~min}$. Finally, the $25 \mathrm{ml}$ of the film forming solutions was poured in the Petri dish for thickness uniformity and conditioned at $30{ }^{\circ} \mathrm{C}$ for $24 \mathrm{~h}$. After adequate drying, the dried films were peeled off and conditioned in a desiccator contained silica gel for $24 \mathrm{~h}$ and stored in petri dishes at room temperature before film characterization were conducted.

\subsubsection{Film thickness measurement}

The film thickness of specimens was measured using a Mitutoyo digital electronic micrometer (Mitutoyo, Japan) to the nearest of $0.001 \mathrm{~mm}$. The average values of five positions were taken and the average values were noted for thickness determination.

\subsubsection{Determination of color parameters}

Color measurements were conducted by colorimetric CEILAB method using a Hunter Lab colorimeter (Hunter Associates Laboratory Inc., USA) with a standard white plate. The colorimeter provided $L^{*}$, a measure of lightness, $a^{*}$ ranging from +60 (redness) to -60 (greenness) and $b^{*}$ ranging from +60 (yellowness) to -60 (blueness) values. The results were obtained in triplicate from ten random measurements of the film surface. Total color difference $\left(\Delta E^{*}\right)$ was defined the difference between two colors and was calculated as follows [27]:

$$
\Delta E^{*}=\sqrt{\left(L^{*}-L\right)^{2}+\left(a^{*}-a\right)^{2}+\left(b^{*}-b\right)^{2}}
$$

Where $\Delta L^{*}, \Delta a^{*}$ and $\Delta b^{*}$ are the difference between each color value of white standard and the corresponding film color parameter.

\subsubsection{Mechanical properties}

Tensile strength (TS) and elongation at break (EAB) were conducted using a texturometer TA.XT2 model (Stable Micro Systems, UK) with a load cell of $5 \mathrm{~kg}$. Rectangular samples $(20 \times 100 \mathrm{~mm})$ were cut, and equilibrated $50 \pm 5 \% \mathrm{RH}$ at $25^{\circ} \mathrm{C}$. The machine was operated in tensile mode and two ends of films were mounted in the film-extension grips and stretched at $50 \mathrm{~mm} \mathrm{~min}^{-1}$. To obtain an average value, eight replicates of each film specimens were measured and the mean values were presented.

\subsubsection{Determination of WVP}

The water vapor permeability (WVP) properties of films was investigated at $25{ }^{\circ} \mathrm{C}$ by using the ASTM E96-05 gravimetric standard for flexible films [28]. An open area of film samples were attached over the openings of permeability cups. Following this, the cups were placed in a desiccator with distilled water at room temperature, and weighed with $1 \mathrm{~h}$ intervals for $10 \mathrm{~h}$ at $25^{\circ} \mathrm{C}$ for the increase of the test cup. The film permeability to water vapor was calculated by Equation 2 . 


$$
W V P=(W V T R \times X) /\left(P_{1}-P_{2}\right)
$$

where $W V T R$ was defined as the water vapor transmission rate ( $\mathrm{g} \mathrm{mm} / \mathrm{kPa} \mathrm{h} \mathrm{m}^{2}$ ) through a film specimen, $X$ was the average thickness $(\mathrm{mm}), P_{1}-P_{2}$ is the partial atmospheric vapor pressure differential between the two sides of the film. Each experiment is repeated three times.

\subsubsection{Determination of water solubility}

Each film specimens ( $2 \mathrm{~cm}$ diameter) were cut and dried to constant weight in an air-circulating oven at $105{ }^{\circ} \mathrm{C}$ to determine the dry matter content. Film specimens were immersed in distilled water $(40 \mathrm{ml})$ for $6 \mathrm{~h}$ at $25{ }^{\circ} \mathrm{C}$. After allowing the water soluble content to dissolve in water, film pieces were left to dry in an oven with air circulation, at $105^{\circ} \mathrm{C}$ until reaching constant weight. Solubility was expressed in terms of dissolved dry mass. The average value of water solubility (WS) was calculated as the mean of three measurements for each film

\subsubsection{Light transmittance and transparency}

Barrier properties for the ultraviolet and visible light transmission (\%) were determined in transmittance mode using an Agilent Cary 60 spectrophotometer with a 200-800 nm wavelength range [29]. Film transparency was defined as follows:

$$
\text { Transparency }=-\log T / x
$$

Where $T$ is transmission (\%) at $600 \mathrm{~nm} ; x$ is film thickness $(\mathrm{mm})$.

\subsubsection{Statistical analysis}

All the results of the study, one-way ANOVA variance analysis was performed and data were analyzed at a confidence level of $p<0.05$.

\section{Results and discussion}

\subsection{Film thickness}

Thickness values of $\mathrm{CH} / \mathrm{CMC}$ films with and without $\mathrm{SiO}_{2}$ nanoparticles are presented in Table 1 . The significant difference $(p<0.05)$ was detected in the thickness values of the $\mathrm{CH} / \mathrm{CMC}$ films with the addition of $\mathrm{SiO}_{2}$ nanoparticles The results revealed that the thickness of $\mathrm{CH} / \mathrm{CMC}$ control film had the smallest thickness value $(0.11 \pm 0.01 \mathrm{~mm}) . \mathrm{CH} / \mathrm{CMC} / \mathrm{NS}$ films increased from $0.12 \pm 0.02$ to $0.15 \pm 0.01$ as the concentration of NS increased from $1 \%$ to $4 \%$ (Table 1). This indicated that the thickness values of $\mathrm{CH} / \mathrm{CMC} / \mathrm{NS}$ film increased significantly $(p<0.05)$ with an increase in the NS content.

Table 1: Thickness values of $\mathrm{CH} / \mathrm{CMC}$ and $\mathrm{CH} / \mathrm{CMC} / \mathrm{NS}$ films.

\begin{tabular}{cc}
\hline NS $(\mathrm{w} / \mathrm{w})$ & Thickness $(\mathrm{mm})$ \\
\hline 0.0 (control) & $0.11 \pm 0.01^{\mathrm{d}}$ \\
1 & $0.12 \pm 0.02^{\mathrm{c}}$ \\
2 & $0.12 \pm 0.02^{\mathrm{c}}$ \\
3 & $0.13 \pm 0.02^{\mathrm{b}}$ \\
4 & $0.15 \pm 0.01^{\mathrm{a}}$ \\
\hline
\end{tabular}

$\overline{\text { Data represent means } \pm \text { SD. Means with the same superscript were compared }}$ vertically for different NS ratios $(p<0.05)$.

Although, the same volume of film forming solution was spread in each petri dishes during the casting process, the solid content of the film forming solutions increases with the incorporation of nanoparticles [30]. Similarly, the increase in thickness was observed when zinc oxide nanoparticles was incorporated into gelatin based films [31].

\subsection{Colorimetric analysis}

A change in color often an indication of a change in physical characteristic so; the color is another important characteristic reflecting the effect of targeted application such as the appearance of the coated product [32]. The color values of film specimens were exhibited in Table 2 . As can be clearly seen in Table 2, the addition of NS, $L^{*}$, and $b^{*}$ values of films increased significantly with the increase in the NS content while $a^{*}$ values decreased significantly. The $\mathrm{CH} / \mathrm{CMC} / \mathrm{NS}$ films were lighter than the $\mathrm{CH} / \mathrm{CMC}$ film $(38.56 \pm 0.15)$. The $a^{*}$ and $b^{*}$ values $\mathrm{CH} / \mathrm{CMC}$ and $\mathrm{CH} / \mathrm{CMC} / \mathrm{NS}$ films were in the following ranges: $a^{*},-0.48 \pm 0.05$ to $-1.03 \pm 0.13$ and $b^{*}, 0.82 \pm 0.15$ to $1.94 \pm 0.45$ (Table 2). Moreover, the values of color difference $\left(\Delta E^{*}\right)$ for the $\mathrm{CH} / \mathrm{CMC}$ films with NS addition of 1, 2, 3 and $4 \%(\mathrm{w} / \mathrm{w})$ were increased with the increase of the amount of NS.

Table 2: Color parameters of $\mathrm{CH} / \mathrm{CMC}$ and $\mathrm{CH} / \mathrm{CMC} / \mathrm{NS}$ films.

\begin{tabular}{ccccc}
\hline $\begin{array}{c}\mathrm{NS} \\
(\mathrm{w} / \mathrm{w})\end{array}$ & $L^{*}$ & $a^{*}$ & $b^{*}$ & $\Delta E^{*}$ \\
\hline $\begin{array}{c}0.0 \\
\text { control })\end{array}$ & $38.56 \pm 0.15^{\mathrm{e}}$ & $-0.48 \pm 0.05^{\mathrm{a}}$ & $0.82 \pm 0.15^{\mathrm{d}}$ & $2.83 \pm 0.54^{\mathrm{d}}$ \\
1 & $38.85 \pm 0.13^{\mathrm{d}}$ & $-0.89 \pm 0.11^{\mathrm{b}}$ & $1.55 \pm 0.36^{\mathrm{c}}$ & $5.49 \pm 0.68^{\mathrm{c}}$ \\
2 & $39.11 \pm 0.20^{\mathrm{b}, \mathrm{c}}$ & $-0.90 \pm 0.08^{\mathrm{b}}$ & $1.66 \pm 0.55^{\mathrm{c}}$ & $7.50 \pm 1.05^{\mathrm{b}}$ \\
3 & $39.37 \pm 0.09^{\mathrm{b}}$ & $-0.96 \pm 0.07^{\mathrm{c}}$ & $1.75 \pm 0.24^{\mathrm{b}}$ & $7.63 \pm 0.90^{\mathrm{b}}$ \\
4 & $39.67 \pm 0.19^{\mathrm{a}}$ & $-1.03 \pm 0.13^{\mathrm{d}}$ & $1.94 \pm 0.45^{\mathrm{a}}$ & $7.96 \pm 0.35^{\mathrm{a}}$ \\
\hline \multicolumn{2}{c}{ Data represent means \pm SD. Means with the same superscript were compared vertically for }
\end{tabular}
different NS ratios $(p<0.05)$.

\subsection{TS and EAB measurement}

Packaging/coating biopolymer films should possess sufficient mechanical strength and extensibility, so as to protect the integrity during handling, packaging and carrying processes [33]. Table 3 gives the values of the TS and $\mathrm{EAB}$ of $\mathrm{CH} / \mathrm{CMC}$ and $\mathrm{CH} / \mathrm{CMC} / \mathrm{NS}$ containing NS with different formulations. The results showed a significant decrease of EAB from $105.71 \pm$ $13.51 \%$ to $41.40 \pm 3.12 \%$ and increase of TS from $6.93 \pm 0.46$ to $12.38 \pm 0.40 \mathrm{MPa}$ after addition of NS. Previous researchers showed NS could strengthen the association through electrostatic attraction, hydrogen bonding or $\mathrm{O}-\mathrm{Si}-\mathrm{O}$ bond between polymeric matrix and metal oxide nanoparticles [21],[34].

Table 3: TS and EAB properties of $\mathrm{CH} / \mathrm{CMC}$ and $\mathrm{CH} / \mathrm{CMC} / \mathrm{NS}$.

\begin{tabular}{ccc}
\hline NS $(w / w)$ & TS $(M P a)$ & EAB $(\%)$ \\
\hline 0.0 (control) & $6.93 \pm 0.46^{\mathrm{d}}$ & $105.71 \pm 13.51^{\mathrm{a}}$ \\
1 & $7.46 \pm 0.51^{\mathrm{c}}$ & $94.58 \pm 6.33^{\mathrm{b}}$ \\
2 & $8.48 \pm 0.98^{\mathrm{b}}$ & $87.16 \pm 12.61^{\mathrm{c}}$ \\
3 & $9.43 \pm 0.78^{\mathrm{a}}$ & $73.25 \pm 6.68^{\mathrm{d}}$ \\
4 & $12.38 \pm 0.40^{\mathrm{a}}$ & $41.40 \pm 3.12^{\mathrm{e}}$ \\
\hline
\end{tabular}

Data represent means \pm SD. Means with the same superscript were compared vertically for different NS ratios $(p<0.05)$.

\subsection{Water vapor permeability}

WVP is the barrier property of films that frequently evaluate the potential of water vapor to be penetrate pass the tortuous path across the packaging film [21],[33]. In general, a higher WVP is one of the shortcomings of natural polymer-based packaging materials due to the hydrophilic nature of proteins. Therefore, a reduced WVP allows movement of moisture across the film and this is a desirable characteristic for to prevent or minimize moisture transfer in coating/packaging applications. Table 4 shows the effects of NS content on WVP values for the different formulations of fabricated $\mathrm{CH} / \mathrm{CMC} / \mathrm{NS}$ films. 
Table 4: WVP of CH/CMC and CH/CMC/NS films.

\begin{tabular}{cc}
\hline NS $(\mathrm{w} / \mathrm{w})$ & WVP $\left(\mathrm{g} \mathrm{mm} / \mathrm{kPa} \mathrm{h} \mathrm{m}^{2}\right)$ \\
\hline 0.0 (control) & $1.75 \pm 0.11^{\mathrm{a}}$ \\
1 & $1.53 \pm 0.14^{\mathrm{b}}$ \\
2 & $1.42 \pm 0.13^{\mathrm{c}}$ \\
3 & $1.34 \pm 0.11^{\mathrm{c}}$ \\
4 & $1.20 \pm 0.18^{\mathrm{d}}$ \\
\hline
\end{tabular}

Data represent means \pm SD. Means with the same superscript were compared vertically for different NS ratios $(p<0.05)$.

From the results obtained (Table 4), the WVP of $\mathrm{CH} / \mathrm{CMC} / \mathrm{NS}$ films decreased significantly as compared to $\mathrm{CH} / \mathrm{CMC}$ films, indicating the potential of NS in strengthen the moisture resistance of $\mathrm{CH} / \mathrm{CMC}$ films. Furthermore, the addition of $4 \%$ $(\mathrm{w} / \mathrm{w})$ NS exhibited the minimum WVP value, revealing that the highest concentration of NS contributed to the lowest degree of hydrophilicity of the $\mathrm{CH} / \mathrm{CMC} / \mathrm{NS}$ film. The hydrogen bond formation between polymer matrix and the oxygen atoms of NS contributed to the lower moisture transfer through $\mathrm{CH} / \mathrm{CMC}$ films [21].

\subsection{Water solubility}

Potentially packaging films are expected to have low WS and water resistance properties against high humidity conditions and direct contact with water are important properties for potentially packaging films [33]. The WS properties of $\mathrm{CH} / \mathrm{CMC}$ films with different NS content were showed in Table 5.

Table 5: WS of $\mathrm{CH} / \mathrm{CMC}$ and $\mathrm{CH} / \mathrm{CMC} / \mathrm{NS}$ films.

\begin{tabular}{cc}
\hline NS $(\mathrm{w} / \mathrm{w})$ & Solubility $(\%)$ \\
\hline $0.0($ control $)$ & $83.72 \pm 4.33^{\mathrm{a}}$ \\
1 & $80.63 \pm 4.94^{\mathrm{b}}$ \\
2 & $74.56 \pm 6.47^{\mathrm{c}}$ \\
3 & $70.27 \pm 7.57^{\mathrm{d}}$ \\
4 & $69.26 \pm 5.61^{\mathrm{d}}$ \\
\hline
\end{tabular}

Data represent means \pm SD. Means with the same superscript were compared vertically for different NS ratios $(p<0.05)$.

The $\mathrm{CH} / \mathrm{CMC}$ film exhibited highest water solubility (83.72 \pm 4.33$)$, whilst $\mathrm{CH} / \mathrm{CMC}$ films incorporated with NS exhibited lower WS values $(p<0.05)$. WS of $\mathrm{CH} / \mathrm{CMC} / \mathrm{NS}$ films decreased with the increase of NS in film formulations $(p<0.05)$. These results pointed out that the strong interaction between NS and polymers in the film matrix improve the formation of network structure, and decreased the water absorption capacity, which would have led to reduce the WS of the films [21],[35]

\subsection{Light transmission and transparency}

Light transmission barrier properties in UV and visible range at wavelengths from 200 to $800 \mathrm{~nm}$, and transparency at $600 \mathrm{~nm}$ of the $\mathrm{CH} / \mathrm{CMC}$ and $\mathrm{CH} / \mathrm{CMC} / \mathrm{NS}$ films are shown in Table 6 . The experimental results showed significant decrease in light transmission with the increased concentration of NS added at 200 and $280 \mathrm{~nm}$, respectively. Lower light transmission for the films indicated an excellent barrier for UV light.
Transparency at $600 \mathrm{~nm}$ for the control $\mathrm{CH} / \mathrm{CMC}$ film was recorded at $2.27 \pm 0.15$. Increasing the concentration of NS in the film formulation from 1 to $4 \%$ significantly increased $(p<0.05)$ the transparency value, strongly suggesting that higher concentrations of NS increased the film transparency.

\section{Conclusions}

The novel biodegradable CH/CMC films were successfully prepared by casting technique using NS as the reinforcing agent. Then the light barrier properties, WVP, WS, TS and EAB properties of the $\mathrm{CH} / \mathrm{CMC}$ and $\mathrm{CH} / \mathrm{CMC} / \mathrm{NS}$ films are investigated. Increased NS content into $\mathrm{CH} / \mathrm{CMC}$ based film greatly affected the properties of $\mathrm{CH} / \mathrm{CMC}$ films. The results indicate that NS has good compatibility with $\mathrm{CH} / \mathrm{CMC}$ films and the addition of NS improved the TS of film. Furthermore, on increasing concentration of NS, also reduced the extensibility, WVP, WS and UV light penetration of the CH/CMC films. Therefore, the novel $\mathrm{CH} / \mathrm{CMC} / \mathrm{NS}$ films with features of safety, biocompatibility and biodegradability could serve as alternative materials for packaging/coating field and provides a reduction in the amount of leather solid waste going to landfills.

\section{References}

[1] Jiang H, Liu J, Han W. "The status and developments of leather solid waste treatment: A mini-review". Waste Management \& Research, 34(5), 399-408, 2016.

[2] Prokein M, Renner M, Weidner E, Heinen T. "Lowchromium- and low-sulphate emission leather tanning intensified by compressed carbon dioxide". Clean Technologies and Environmental Policy, 19(10), 2455-2465, 2017.

[3] Gil CSB, Gil VSB, Carvalho SM, Silva GR, Magalhaes JH, Orefice RL, Mansur A, Mansur HS, Patricio PSO, Oliveria LCA. "Recycled collagen films as biomaterials for controlled drug delivery". New Journal of Chemistry, 40(10), 8502-8510, 2016.

[4] Kupec J, Dvorackova M, Rudlova S, Ruzicka J, Kolomaznik K. "Deproteination of chrome waste by washing and enzymatic hydrolysis". Journal of the American Leather Chemists Association, 97(9), 349-354, 2002.

[5] Lipsett AV. "Offal Blue". Journal of the American Leather Chemists Association, 77(6), 291-301, 1982.

[6] Ocak B. "Complex coacervation of collagen hydrolysate extracted from leather solid wastes and chitosan for controlled release of lavender oil". Journal of Environmental Management, 100, 22-28, 2012.

[7] Zhou J, Xu T, Wang X, Liu C, Liao X, Huang X, Shi B. "A low-cost and water resistant biomass adhesive derived from the hydrolysate of leather waste". RSC Advances, 7(7), 4024-4029, 2017.

Table 6: Light transmittance (\%) and transparency values of $\mathrm{CH} / \mathrm{CMC}$ and $\mathrm{CH} / \mathrm{CMC} / \mathrm{NS}$ films at different formulation.

\begin{tabular}{clllllllll}
\hline & \multicolumn{7}{c}{ Light transmission at different wavelengths (\%) } \\
\hline NS (w/w) & $200 \mathrm{~nm}$ & $280 \mathrm{~nm}$ & $350 \mathrm{~nm}$ & $400 \mathrm{~nm}$ & $500 \mathrm{~nm}$ & $600 \mathrm{~nm}$ & $700 \mathrm{~nm}$ & $800 \mathrm{~nm}$ & Transparency at $600 \mathrm{~nm}$ \\
\hline 0.0 (control) & 0.10 & 2.65 & 35.50 & 56.94 & 66.47 & 73.87 & 77.30 & 80.58 & $2.27 \pm 0.15^{\mathrm{d}}$ \\
1 & 0.07 & 0.98 & 25.34 & 38.29 & 52.11 & 58.48 & 60.56 & 62.40 & $3.24 \pm 0.45^{\mathrm{c}}$ \\
2 & 0.04 & 0.87 & 13.80 & 22.08 & 29.34 & 34.21 & 36.33 & 37.51 & $5.15 \pm 0.15^{\mathrm{b}}$ \\
3 & 0.03 & 0.46 & 10.15 & 17.86 & 20.98 & 27.38 & 29.65 & 30.95 & $5.60 \pm 0.26^{\mathrm{b}}$ \\
4 & 0.02 & 0.12 & 4.85 & 9.35 & 14.10 & 17.63 & 18.64 & 20.07 & $7.27 \pm 0.31^{\mathrm{a}}$ \\
\hline
\end{tabular}

Data represent means \pm SD. Means with the same superscript were compared vertically for different NS ratios $(p<0.05)$. 
[8] Ocak B, Aslan A, Gulumser G. "Utilization of chromiumtanned leather solid wastes in microencapsulation". Journal of the American Leather Chemists Association, 106(7), 232-238, 2011.

[9] Kocurek P, Kolomaznik K, Barinova M, Hendrych J. “Total control of chromium in tanneries- thermal decomposition of filtration cake from enzymatic hydrolysis of chrome shavings". Waste Management \& Research, 35(4), 444-449, 2017.

[10] Cabeza LF, Taylor MM, DiMaio GL, Brown EM, Marmer WN, Carrio R, Celma PJ, Cot J. "Processing of leather waste: pilot scale studies on chrome shavings. Isolation of potentially valuable protein products and chromium". Waste Management, 18(3), 211-218, 1998.

[11] Ocak B. "Film-forming ability of collagen hydrolysate extracted from leather solid wastes with chitosan". Environmental Science and Pollution Research, 25(5), 4643-4655, 2018.

[12] Castiello D, Chiellini E, Cinelli P, D’Antone S, Puccini M, Salvadori M, Seggiani M. "Polyethylene-collagen hydrolizate thermoplastic blends: Thermal and mechanical properties". Journal of Applied Polymer Science, 114(6), 3827-3834, 2009.

[13] Haroun AA. "Preparation and characterization of biodegradable thermoplastic films based on collagen hydrolyzate". Journal of Applied Polymer Science, 115(6), 3230-3237, 2010.

[14] Hazirah MASPN, Isa MIN, Sarbon NM. "Effect of xanthan gum on the physical and mechanical properties of gelatincarboxymethyl cellulose film blends". Food Packaging and Shelf Life, 9, 55-63, 2016.

[15] Nazmi NN, Isa MIN, Sarbon NM. "Preparation and characterization of chicken skin gelatin/CMC composite film as compared to bovine gelatin film". Food Bioscience, 19, 149-155, 2017.

[16] Szusta J, Karakas O, Tomczyk A. "Experimental investigation of thin films with various overprints used for packaging labels". Theoretical and Applied Fracture Mechanics, 97, 467-477, 2018.

[17] Voon HC, Bhat R, Easa AM, Liong MT, Karim AA. "Effect of addition of halloysite nanoclay and $\mathrm{SiO}_{2}$ nanoparticles on barrier and mechanical properties of bovine gelatin films". Food and Bioprocess Technology, 5(5), 1766-1774, 2012.

[18] Hanani ZAN, Roos YH, Kerry JP. "Use and application of gelatin as potential biodegradable packaging materials for food products". International Journal of Biological Macromolecules, 71, 94-102, 2014.

[19] Venkatesan R, Rajeswari N, Thiyagu TT. "Preparation, characterization and mechanical properties of $\mathrm{k}$ Carrageenan $/ \mathrm{SiO}_{2}$ nanocomposite films for antimicrobial food packaging". Bulletin of Materials Science, 40(3), 609-614, 2017.

[20] Ahmad M, Benjakul S, Prodpran T, Agustini TW. "Physicomechanical and antimicrobial properties of gelatin film from the skin of unicorn leatherjacket incorporated with essential oils". Food Hydrocolloids, 28(1), 189-199, 2012.

[21] Hassannia-Kolaee M, Khodaiyan F, Pourahmad R, Shahabi-Ghahfarrokhi I. "Development of ecofriendly bionanocomposite: Whey proteinisolate/pullulan films with nano-SiO2". International Journal of Biological Macromolecules, 86, 139-144, 2016.
[22] Pei Y, Yang J, Liu P, Xu M, Zhang X, Zhang L. "Fabrication, properties and bioapplications of cellulose/collagen hydrolysate composite films". Carbohydrate Polymers, 92(2), 1752-1760, 2013.

[23] Estevez M, Vargas S, Castano VM, Rodriguez R. "Silica nano-particles produced by worms through a biodigestion process of rice husk". Journal of Non-Crystalline Solids, 355(14-15), 844-850, 2009.

[24] Dong Y, Liu T, Sun S, Chang X, Guo N. "Preparation and characterization of $\quad \mathrm{SiO}_{2}$ /polydopamine/Ag nanocomposites with long-term antibacterial activity". Ceramics International, 40(4), 5605-5609, 2014.

[25] Pan H, Li GL, Liu RQ, Wang SX, Wang XD. "Preparation, characterization and application of dispersible and sphericalnnano-SiO ${ }_{2} @$ copolymer nanocomposite in leather tanning". Applied Surface Science, 426, 376-385, 2017.

[26] Rahman IA, Padavettan V. "Synthesis of silica nanoparticles by sol-gel: size-dependent properties, surface modification, and applications in silica-polymer nanocomposites-a review". Journal of Nanomaterials, 8, 1-15, 2012.

[27] Gennadios A, Weller CL, Hanna MA, Froning GW. "Mechanical and barrier properties of egg albumen films". Journal of Food Science, 61(3), 585-589, 1996.

[28] American Society for Testing Materials. "Standard Test Method for Water Vapor Transmission of Materials (E 9605)". Philadelphia, USA, Annual Book of ASTM Standards, 14, 2005.

[29] Hosseini SF, Rezaei M, Zandi M, Farahmandghavi F. "Biobased composite edible films containing Origanum vulgare L. essential oil". Industrial Crops and Products, 67, 403-413, 2015.

[30] Kadam DM, Thunga M, Wang S, Kessler MR, Grewell D, Lamsal B, Yu C. "Preparation and characterization of whey protein isolate films reinforced with porous silica coated titania nanoparticles". Journal of Food Engineering, 117(1), 133-140, 2013.

[31] Shankar S, Teng X, Li G, Rhim JW. "Preparation, characterization, and antimicrobial activity of gelatin/ZnO nanocomposite films". Food Hydrocolloids, 45, 264-271, 2015.

[32] Chitprasert P, Ngamekaue N. "Stability enhancement of Ocimum Sanctum Linn. essential oils using stearic acid in aluminum carboxymethyl cellulose film-coated gelatin microcapsules". Journal of Food Science, 82(6), 1310-1318, 2017.

[33] Ge L, Zhu M, Xu Y, Li X, Li D, Mu C. "Development of antimicrobial and controlled biodegradable gelatin-based edible films containing nisin and amino-functionalized montmorillonite". Food and Bioprocess Technology, 10(9), 1727-1736, 2017.

[34] Mu C, Guo J, Li X, Lin W, Li D. "Preparation and properties of dialdehyde carboxymethyl cellulose crosslinked gelatin edible films". Food Hydrocolloids, 27(1), 22-29, 2012.

[35] Guo J, Li X, Mu C, Zhang H, Qin P, Li D. "Freezing-thawing effects on the properties of dialdehyde carboxymethyl cellulose crosslinked gelatin-MMT composite films". Food Hydrocolloids, 33(2), 273-279, 2013. 